Chirurgia (2018) 113: 335-343

No. 3, May - June

Copyright $\odot$ Celsius

http://dx.doi.org/10.21614/chirurgia.113.3.335

\title{
What is the Value of Total Mesopancreas Excision in Pancreatic Ductal Adenocarcinoma? Current Evidence of the Literature
}

\author{
Irinel Popescu ${ }^{1,2}$, Traian Dumitrascu ${ }^{1,3}$ \\ 1"Dan Setlacec" Center of General Surgery and Liver Transplantation, Fundeni Clinical Institute, Bucharest, Romania \\ 2"Titu Maiorescu" University, Bucharest, Romania \\ "Carol Davila" University of Medicine and Pharmacy, Bucharest, Romania
}

Corresponding author:

Traian Dumitrascu, MD

"Dan Setlacec" Center of General

Surgery and Liver Transplantation

Fundeni Clinical Institute

Fundeni Street no 258, 022328

Bucharest Romania

E-mail: traian.dumitrascu@umfcd.ro

\section{Rezumat}

Care este valoarea exciziei complete a mezopancreasului în carcinomul ductal pancreatic? Analiza datelor din literatură

Carcinomul ductal pancreatic (PDAC) este o afecțiune cu prognostic infaust. Rezecția pancreatică reprezintă singura şansă de supraviețire pe termen lung în cazul unui pacient diagnosticat cu PDAC. Recidiva după chirurgia cu viză curativă pentru PDAC este frecventă şi se datorează în cea mai mare parte marginilor de rezecție pozitive: marginea medială/ de la nivelul arterei mezenterice superioare cel mai frecvent. Excizia completă a mezopancreasului (TMpE) a fost propusă în analogie cu excizia totală a mezorectului în cancerul rectal, pentru un mai bun control al recidivei loco-regionale. Lucrarea îşi propune să discute datele existente la momentul actual în literatura de specialitate privind valoarea TMpE în PDAC.

Cuvinte cheie: carcinom ductal pancreatic, pancreatectomie, mezopancreas, excizie completă de mezopancreas, recidivă, supraviețire

\begin{abstract}
Pancreatic ductal adenocarcinoma (PDAC) is a disease with a grim prognosis. Pancreatectomy represents the single hope for long-term survival in a patient with PDAC. Recurrence is a common event after curative-intent surgery for PDAC, mainly related to incomplete removal at the site of resection margins; medial/ superior mesenteric margins are the most often positive. The concept of total meso-
\end{abstract}


pancreas excision (TMpE) in PDAC was proposed in analogy to the concept of total mesorectal excision for rectal cancer, to better control loco-regional recurrence. This paper aims to discuss the current evidence for the value of TMpE in PDAC.

Key words: pancreatic ductal adenocarcinoma, pancreatectomy, mesopancreas, total mesopancreas excision, recurrence, survival

\section{Introduction}

Pancreatic ductal adenocarcinoma (PDAC) remains in 2017 an important cause of death by cancer both in the United States and Europe $(1,2)$. More than $80 \%$ of patients with PDAC have locally advanced and/or metastatic disease at the time of diagnosis (2). Thus, the prognosis of most patients diagnosed with $\mathrm{PDAC}$ is grim, with a 5-year survival rate of $8 \%$ for all stages (2).

Pancreatectomies represent the single hope for a long-term survival in a patient with PDAC but are possible in less than $20 \%$ of the patients (2). A study performed in the United States based on data from Surveillance, Epidemiology, and End Results registry has shown that a pancreatectomy is associated with statistically significant increased survivals for patients with resectable PDAC (i.e., stage I/ II), compared with any other form of therapy (3). Furthermore, a recent study performed in the Netherlands has shown that the percentage of patients with PDAC who survived more than 5 years is significantly higher after resection (10.1\%), compared with patients with unresected localized or metastatic disease $(0.5 \%$ and $0.1 \%$, respectively)(4). Median overall survival time after resection for PDAC is approximately two years (5-8).

In patients with resectable PDAC, the prognosis is driven mainly by tumor-related factors (i.e., tumor diameter, differentiation grade, lymph node status and ratio, and involvement of surgical margins) and completion of adjuvant therapy (9). Thus, one might question what could be the contribution of a surgeon to better prognosis in a patient with PDAC?
Increased resectability and reduced postoperative mortality rates are the main contributions of a surgeon to better prognosis in a patient diagnosed with PDAC and are feasible if patients are operated in high-volume centers by high case-load surgeons (10-13).

In the last years, although several signs of progress have been observed in adjuvant therapy for PDAC (14), these advances in developing effective treatments are by far too modest. At the same time, several potential improvements were proposed to better resect PDAC, including total mesopancreas excision (TMpE) (15).

Initially, a systematic review of the literature performed in 2008 did not show any significant improvements for overall survivals after resection for PDAC (6). However, a study published in 2017 including 15604 patients with pancreatectomies for PDAC has shown that median survival time has significantly increased from 14 months between 1992 1997 to 18 months between $2004-2010$ (16).

This paper aims to discuss the current evidence for the value of TMpE in PDAC. It is worth to mention that in the literature there are used the following terms: total mesopancreas (meso-pancreas) excision(15,17-20) and total meso-pancreatoduodenum excision $(21,22)$.

\section{What are the recurrence rates and resection margins status after curative-intent surgery for PDAC?}

Recurrence after curative-intent surgery for PDAC is unfortunately a common event $-75 \%$ - $100 \%$ of patients(15,23-25); a local recurrence is the first reported event for most patients with recurrent PDAC(7;26). Incomplete lymph 
nodes or perineural dissection are considered factors associated with local recurrence after resection for PDAC (23). Furthermore, local recurrence occurs more frequently in patients with positive resection margins (26). Thus, negative resection margins operative specimen is of utmost importance in patients with resected PDAC (15).

Negative resection margins rates reported in the literature recognize a large variability, due to different definitions and techniques for assessment (26), mainly related to pathological evaluation (27).

In a meta-analysis performed in 2008 , the reported incidence of positive resection margins after curative-intent surgery for PDAC was up to $32 \%$ of patients, with no impact on long-term outcomes (28). However, for these patients no standardized pathology protocol was used (28).

Standardization of protocol for pathological examination has lead to increased reported positive resection margins rates after pancreaticoduodenectomies (PD) for PDAC: $71 \%$ - 84.6\% (29-34).

Recent systematic review and metaanalyses have noticed that overall incidence of negative resection margins ranged between $8.1 \%$ and $84 \%(26,35,36)$. The medial/ superior mesenteric artery margin was the most often positive, ranging between $15 \%$ and $45 \%$ $(26,35)$. Studies concluded that positive resection margins have a detrimental effect on long-term outcome after resection for PDAC $(26,35,36)$, and the inability to clear the medial/superior mesenteric artery margin represents the most important cause of incomplete resection $(26,35)$.

A recent study performed in Heidelberg has shown that positive resections margins are associated with significantly decreased overall survival and recurrence-free rates (7). Thus, median overall survival time and recurrencefree rate in patients with negative resections margins were significantly higher, compared with patients with positive margins (24.9 months vs. 18.7 months and 15.7 months vs. 11.9 months, respectively)(7). Positive resections margins were by far more frequently observed to the medial margins (7).

The use of standardized pathological protocol to assess margins after resection for PDAC has shown that overall survival rates are significantly different between positive and negative resection margins patients (10.5 - 23.4 months vs. 18.9 - 41.6 months) (29,31-34).

Positive resection at the medial/ superior mesenteric margins is widely considered to have a significant impact on both recurrence and overall survival rates in PDAC $(24,31)$. A study published in 2010 has shown that overall survival time in patients with positive transection margins (including medial/superior mesenteric margins) is significantly worse, compared with patients with positive mobilization margins (31).

In conclusion, a recurrence is a common event after curative-intent surgery for PDAC, mainly related to incomplete removal at the site of resection margins. Although negative resection margins are the main goal of curativeintent surgery for PDAC and were associated with improved survivals, however, positive resection margins rates are highly reported after pancreatectomies for PDAC, even in highvolume centers, when standardized pathology protocols are used. Medial/ superior mesenteric margins are the most often positive, with a detrimental effect on both recurrence and overall survival rates in PDAC.

\section{What is the mesopancreas and what is the technique of TMpE?}

The concept of TMpE in PDAC was proposed in analogy to the concept of total mesorectal excision for rectal cancer, to better control locoregional recurrence $(23,37)$.

As already shown, loco-regional recurrence is a frequent event after curative-intent surgery for PDAC and appears to be related with high incidence of tumor invasion and high positive resection margins rates at medial/superior mesenteric artery margins (23). A local recurrence is widely considered to be generated by incomplete removal at the site of resection (38). Thus, a technique to better resect the retro- 
pancreatic area would be of interest and another potential contribution of pancreatic surgeons to improved outcomes in PDAC.

It is the merit of Goekel and co-workers (37) to introduce the concept of TMpE in PDAC, a concept that recognized furthermore a great interest, is considered a promising surgical technique for patients with PDAC (39).

Goeckel and co-workers described for the first time the mesopancreas as firm and wellvascularized structure (perineural lymphatic layer) extending from posterior surface of the pancreatic head to behind the superior mesenteric vessels (37). En-bloc resection of this structure during PD for PDAC was suggested, following a perineural plane (37).

Several other anatomical studies have shown that the structure namely considered mesopancreas contain loose connective tissues, fat, lymph nodes, lymphatic and nerves, along with small blood vessels, but there is no fascia of fibrous layer to cover the mesopancreas, as it is the case for mesorectum (40,41) (Fig. 1). Thus, a dissection plane for TMpE does not appear to exist to allow en-bloc resection (40); however, instead, subadventitial dissection of superior mesenteric artery is suggested to resect the mesopancreas (41).

Some authors consider the mesopancreas as soft connective tissue situated along the inferior pancreatico-duodenal artery and first jejunal

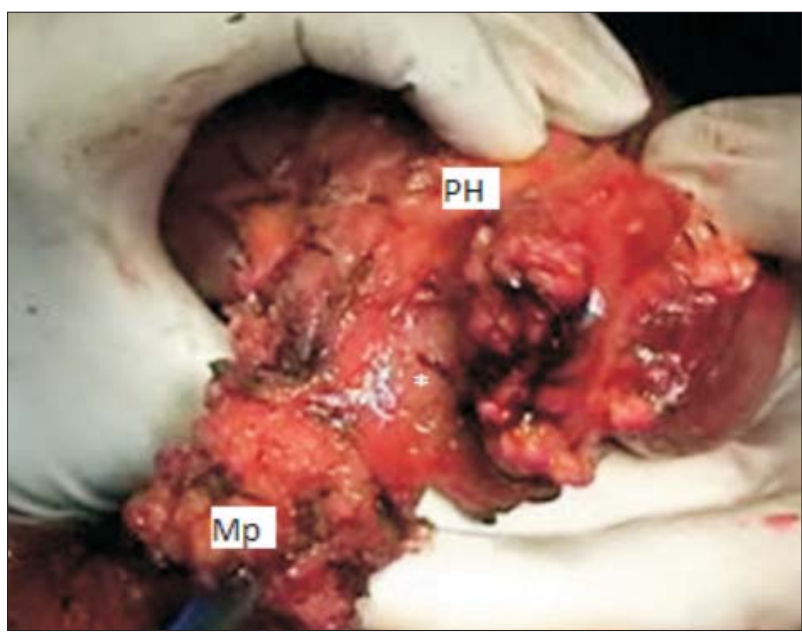

Figure 1. Operative specimen of pancreatico-duodenectomy for pancreatic head ductal adenocarcinoma ( $\mathrm{PH}$ - pancreatic head; $\mathrm{Mp}$ - mesopancreas)

artery, and developed surgical techniques to resect the mesopancreas guided by the course of these arteries (21,22) (Fig. 2 and 3).

Nevertheless, there are also authors that consider mesopancreas a misnomer because it does not include all the blood supply and lymphatic networks of the pancreatic head (42). The term suggested to replace mesopancreas is pancreatic head plexus II (nerve tissue distributed to uncinate process from superior mesenteric artery plexus, including inferior pancreatico-duodenal artery), as Japan Pancreas Society recently proposed $(42,43)$. Other terms used in the literature to describe

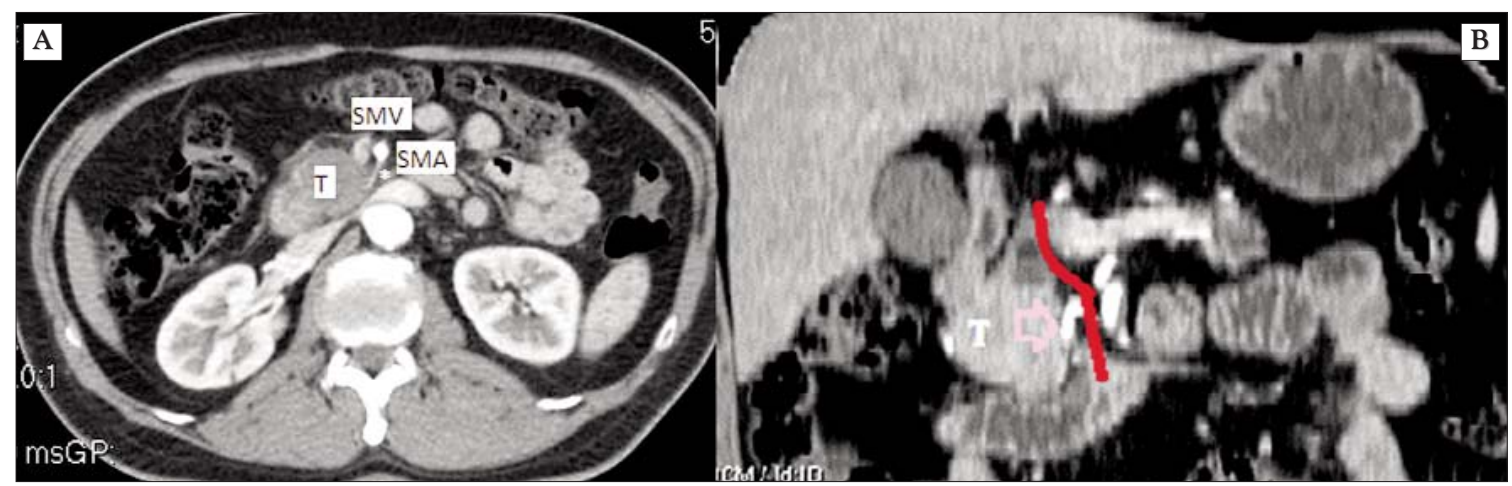

Figure 2. Preoperative assessment of a pancreatic head ductal adenocarcinoma ( $\mathrm{T}$ ) by contrast enhanced computed tomography (A) coronal plane and (B) frontal plane to guide pancreatico-duodenectomy with total mesopancreas excision by inferior pancreatico-duodenal artery ( ${ }^{*}$ and arrow marks the inferior pancreaticoduodenal artery; SMA - superior mesenteric artery; SMV - superior mesenteric vein; the line marks the plane for transection). 


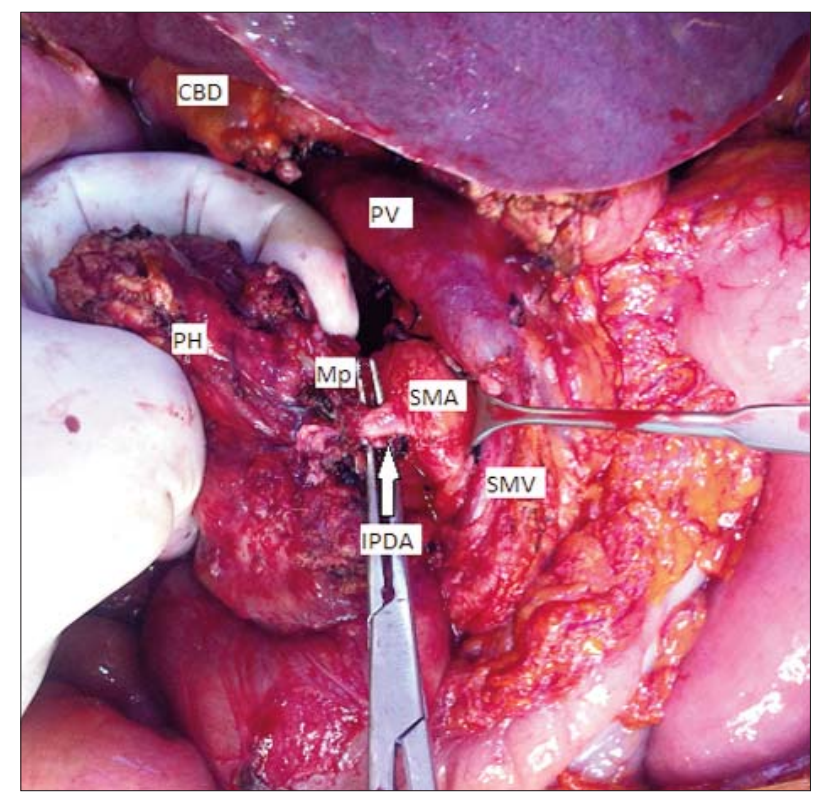

Figure 3. Intraoperative aspects of pancreatico-duodenectomy with total mesopancreas excision guided by inferior pancreatico-duodenal artery (IPDA - inferior pancreatico-duodenal artery; SMA - superior mesenteric artery; SMV - superior mesenteric vein; PV - portal vein; CBD - common bile duct; $\mathrm{PH}$ - pancreatic head; $\mathrm{Mp}$ - mesopancreas)

the structure of mesopanceas are retroportal lamina or retroportal pancreas (23).

Gaedcke and co-workers analyzing the operative specimens of PD for periampullary malignancies observed tumor infiltration of mesopancreas in approximately two-thirds of patients with positive resection margins (38). Thus, the authors concluded that mesopancreas is the primary site for positive resection margins (38).

We have previously emphasized the key role of TMpE in PDAC (15). However, it is the merit of Adham and co-workers to describe for the first time in 2012 the detailed technique for a standardized TMpE (17) (Fig. 4).

According to Adham and co-workers, the right side of superior mesenteric artery represents the inferior resection margin of mesopancreas, the origin of celiac trunk represents the posterior resection margin, while the right side of the celiac trunk represents the superior resection margin of mesopancreas (17). Thus, the mesopancreas is considered a triangular flap of tissues (including lymph nodes, lymphatic and nerve plexus, small arteries and veins) that extend from the posterior part of pancreatic head behind the superior mesenteric/ portal vein (17).

Furthermore, several other techniques of $\mathrm{TMpE}$ were described in the literature (18-21,23,44-47).

Resection of mesopancreas is included in standard pancreatectomy by most pancreatic surgeons $(25,48)$, while others consider it extended lymph nodes dissection (49-51).

A review published in 2013 highlighted the fact that TMpE is not only a matter of lymph

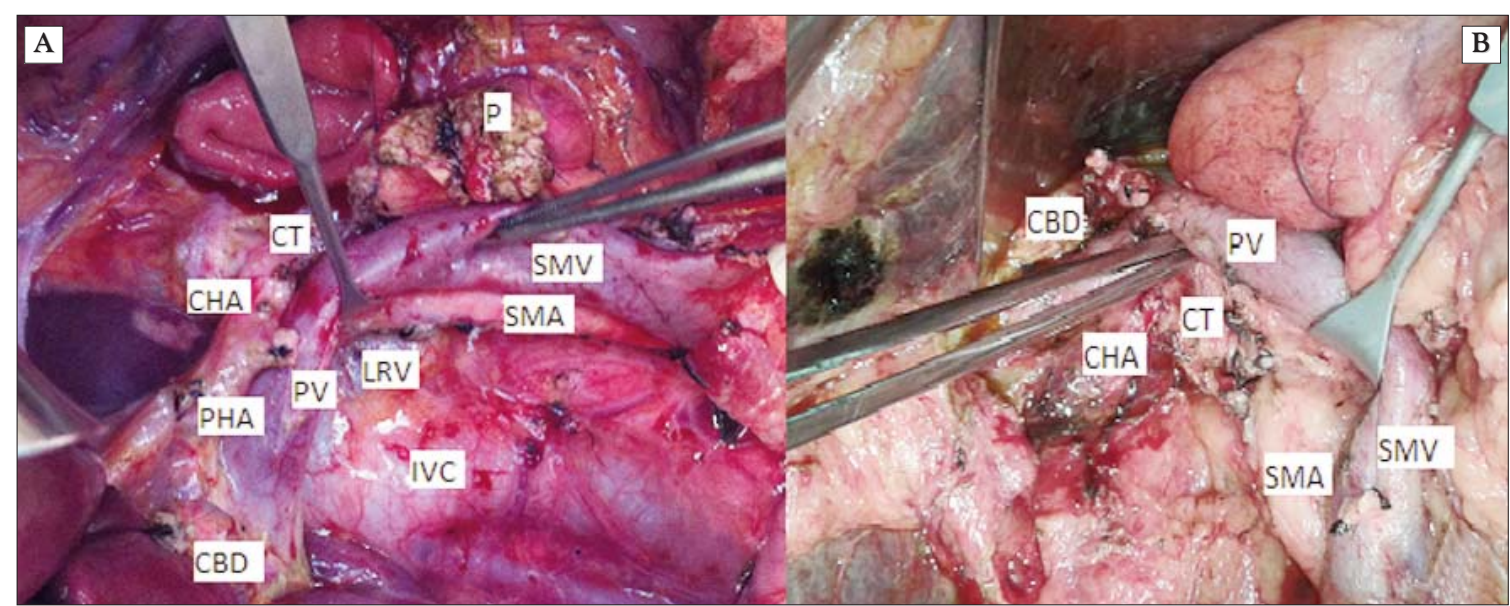

Figure 4. Intraoperative aspects after pancreatico-duodenectomy with total mesopancreas excision (IVC - inferior vena cava; LRV - left renal vein; CT - celiac trunk; CHA - common hepatic artery; PHA - proper hepatic artery; SMA - superior mesenteric artery; SMV - superior mesenteric vein; PV - portal vein; CBD - common bile duct; $P$ - distal pancreas). 
nodes dissection but also refers to excision of perivascular neural and soft tissues, including the extrapancreatic nerve plexus (50). Furthermore, TMpE is considered mandatory to minimize the chance of positive resection margins at this level $(50,52)$.

In conclusion, mesopancreas might be a misnomer without precise anatomical boundaries but contains important lymphatic and nervous plexus. Thus, mesopancreas represent a space of utmost importance for resection margins and tumor recurrence in PDAC. Furthermore, $\mathrm{TMpE}$ is a real surgical concept that should be standard for any PD for PDAC because it allows increased rates of negative resection margins.

\section{What are the technical refinements developed to facilitate TMpE?}

Nakao proposed in 1993 the mesenteric approach in PD to achieve complete resection of the mesopancreas in PDAC $(43,53)$.

Several other technical refinements, grouped as "artery-first" approaches, were proposed to better resect PDAC of the pancreatic head, including TMpE (19-21,45,47,54-59).

$\mathrm{Xu}$ and $\mathrm{co}^{-}$workers in a review have shown the potential benefit for improvement of outcomes of "artery-first" PD for PDAC (60). Furthermore, a recent systematic review and meta-analysis has emphasized the reduced loco-regional recurrence rate after "artery-first" approaches for PDAC, compared with standard approach, albeit no significant differences were observed for negative resection margins and overall survivals rates (61).

However, another recent review has shown that there is no clear benefit of "artery-first" approaches to decrease positive resection margins rates or to improve survivals in PDAC (62).

Nevertheless, institutional studies published in 2017 have shown a potential benefit of survival in PDAC with an "artery-first" approach, albeit the statistical significance was not reached $(63,64)$.

In conclusion, "artery-first" approaches appear to facilitate TMpE during PD for PDAC (Fig. 5).

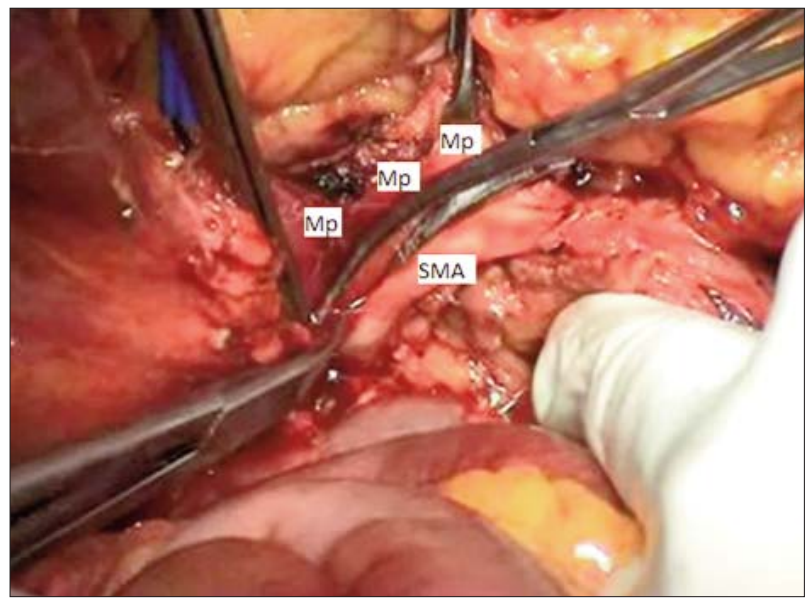

Figure 5. Intraoperative aspects of pancreatico-duodenectomy with posterior approach and total mesopancreas excision (Mp - mesopancreas; SMA - superior mesenteric artery)

\section{What is the impact of TMpE on early and long- term outcomes in patients with PDAC?}

We have previously highlighted the critical role of TMpE in PDAC (15) and developed it furthermore in clinical practice (65).

Kurosaki and co-workers have found significant differences in overall survivals between patients resected for PDAC with and without TMpE, in favor for patients with TMpE (44). Interestingly, no differences in positive resection margins rates were observed between the groups (44).

Kawabata and co-workers have found significantly increased number of harvested lymph nodes and negative resection margins rates when TMpE was performed (21). Updated data have associated TMpE with significantly less blood loss and decreased loco-regional recurrence rates (66). However, further analyses did not show any significant improvements for overall survivals for both biliary tract cancers (67) and PDAC (68).

Aimoto and co-workers have found significantly more harvested lymph nodes, less blood loss and less local recurrence rates in patients with PD for PDAC and TMpE, compared with standard approach (18).

Perinel and co-workers have found significantly increased number of retrieved lymph 
nodes and improved survivals when TMpE was performed (25).

Inoue and co-workers have found significantly less blood loss when TMpE was performed (19). Furthermore, no impact was observed for number of retrieved lymph nodes or positive resection margins rates (69).

Sugiyama and co-workers have found significantly less blood loss when TMpE was performed (46).

Our previous studies have shown significantly less blood loss but no improved survivals with TMpE and posterior approach PD (54).

In summary, the data from the literature regarding outcomes after $\mathrm{PD}$ with $\mathrm{TMpE}$ for periampullary malignancies have shown negative resection margins rates between $71.6 \%$ and $86 \%$, tumor infiltration of the mesopancreas in $23.1 \%-82.5 \%$ of patients, a median number of harvested lymph nodes between 7.9 and 34, morbidity rates between $33 \%$ and $71 \%$, mortality rates between $0 \%$ and $5.7 \%$, and median overall survival times between 18.3 months and 20.5 months $(17,18$, 20,44-46,54,55,68).

At this time, although TMpE appears to be widely considered a key point in resection for PDAC of the pancreatic head $(15,20,52)$, however, it is too early to conclude that it has the same oncological value as total mesorectal excision in rectal cancer $(70,71)$.

A recent study has shown that there are important anatomical differences between the mesorectum and mesopancreas (72):

- a fascia envelops all the structures of mesorectum and allows dissection in an extrafascial plane, which is not the case for mesopancreas;

- the rectal fascia is a landmark for pathology and adequate surgical resection, which is not the case for mesopancreas;

- a circumferential resection margin results from en-bloc resection of the rectum and mesorectum, which is not the case for mesopancreas

-the prognostic impact of circumferential resection margin status can be assessed with respect to the completeness of total mesorectal excision on the plane of rectal fascia, a situation that cannot be accomplished for mesopancreas that has no anatomic boundaries.

Nevertheless, Verbeke and co-workers have shown that tumor growth is more dispersed in pancreatic head PDAC than in rectal cancer (73).

In conclusion, TMpE with PD for PDAC is feasible and safe and was associated with decreased blood loss, increased number of harvested lymph nodes and negative resection margins rates. However, data about improved survivals in PDAC with TMpE are scarce and, thus, it is too early to conclude that TMpE has the same oncological value as total mesorectal excision in rectal cancer.

\section{Conclusions}

Mesopancreas might be a misnomer without precise anatomical boundaries but contains important lymphatic and nervous plexus. Thus, mesopancreas represent a space of utmost importance for resection margins and tumor recurrence in PDAC.

TMpE is a real surgical concept that should be standard for any PD for PDAC because it is safe and feasible, and allows increased number of harvested lymph nodes and increased rates of negative resection margins.

However, data about improved survivals in PDAC with TMpE are scarce and, thus, it is too early to conclude that TMpE has the same oncological value as total mesorectal excision in rectal cancer.

Further studies are urgently needed to draw reliable conclusions.

\section{Funding and conflict of interests: none}

\section{References}

1. Malvezzi M, Carioli G, Bertuccio P, Boffetta P, Levi F, La Vecchia C, et al. European cancer mortality predictions for the year 2017, with focus on lung cancer. Ann Oncol 2017;28(5):1117-23.

2. Siegel RL, Miller KD, Jemal A. Cancer Statistics, 2017. CA Cancer $\mathrm{J}$ Clin 2017;67(1):7-30.

3. McDowell BD, Chapman CG, Smith BJ, Button AM, Chrischilles EA, Mezhir JJ. Pancreatectomy predicts improved survival for pancre- 
atic adenocarcinoma: results of an instrumental variable analysis Ann Surg 2015;261(4):740-5.

4. Zijlstra M, Bernards N, de Hingh IH, van de Wouw AJ, Goey SH, Jacobs EM, et al. Does long-term survival exist in pancreatic adenocarcinoma? Acta Oncol 2016;55(3):259-64.

5. Dumitrascu T, Dima S, Brasoveanu V, Stroescu C, Herlea V, Moldovan $S$, et al. Impact of a portal/superior mesenteric vein resection during pancreatico-duodenectomy for pancreatic head adenocarcinoma. Minerva Chir 2014;69(6):301-13.

6. Garcea G, Dennison AR, Pattenden CJ, Neal CP, Sutton CD, Berry DP. Survival following curative resection for pancreatic ductal adenocarcinoma. A systematic review of the literature. JOP 2008 ;9(2):99-132

7. Ghaneh P, Kleeff J, Halloran CM, Raraty M, Jackson R, Melling J, et al. The Impact of Positive Resection Margins on Survival and Recurrence Following Resection and Adjuvant Chemotherapy for Pancreatic Ductal Adenocarcinoma. Ann Surg 2017 Oct 24. Doi: 10.1097/SLA.0000000000002557. [Epub ahead of print]

8. Lewis R, Drebin JA, Callery MP, Fraker D, Kent TS, Gates J, et al. A contemporary analysis of survival for resected pancreatic ductal adenocarcinoma. HPB (Oxford) 2013:15(1):49-60.

9. Neuzillet C, Tijeras-Raballand A, Bourget P, Cros J, Couvelard A, Sauvanet $A$, et al. State of the art and future directions of pancreatic ductal adenocarcinoma therapy. Pharmacol Ther 2015;155:80-104.

10. Gooiker GA, van GW, Wouters MW, Post PN, van de Velde CJ, Tollenaar RA. Systematic review and meta-analysis of the volume-outcome relationship in pancreatic surgery. Br J Surg 2011;98(4):485-94

11. Gooiker GA, Lemmens VE, Besselink MG, Busch OR, Bonsing BA Molenaar IQ, et al. Impact of centralization of pancreatic cancer surgery on resection rates and survival. Br J Surg 2014;101(8):1000-5.

12. Mathur A, Luberice K, Ross S, Choung E, Rosemurgy A Pancreaticoduodenectomy at High-volume Centers: Surgeon Volume Goes Beyond the Leapfrog Criteria. Ann Surg 2015;262(2):e37-e39.

13. Popescu I, Dumitrascu T. [Pancreatoduodenectomy--past, present and future]. Chirurgia (Bucur ) 2011;106(3):287-96.

14. Liao WC, Chien KL, Lin YL, Wu MS, Lin JT, Wang HP, et al. Adjuvant treatments for resected pancreatic adenocarcinoma: a systematic review and network meta-analysis. Lancet Oncol 2013;14(11):1095-103.

15. Popescu I, Dumitrascu T. Total meso-pancreas excision: key point of resection in pancreatic head adenocarcinoma. Hepatogastroenterology 2011;58(105):202-7.

16. Luberice K, Downs D, Sadowitz B, Ross S, Rosemurgy A. Has survival improved following resection for pancreatic adenocarcinoma? Am J Surg 2017;214(2):341-6.

17. Adham M, Singhirunnusorn J. Surgical technique and results of total mesopancreas excision (TMpE) in pancreatic tumors. Eur $\mathrm{J}$ Surg Oncol 2012;38(4):340-5.

18. Aimoto T, Mizutani S, Kawano Y, Matsushita A, Yamashita N, Suzuki $\mathrm{H}$, et al. Left posterior approach pancreaticoduodenectomy with total mesopancreas excision and circumferential lymphadenectomy around the superior mesenteric artery for pancreatic head carcinoma. J Nippon Med Sch 2013;80(6):438-45.

19. Inoue Y, Saiura A, Yoshioka R, Ono Y, Takahashi M, Arita J, et al. Pancreatoduodenectomy With Systematic Mesopancreas Dissection Using a Supracolic Anterior Artery-first Approach. Ann Surg 2015;262(6):1092-101.

20. Wu W, Wang X, Wu X, Li M, Weng H, Cao Y, et al. Total mesopancreas excision for pancreatic head cancer: analysis of 120 cases. Chin J Cancer Res 2016;28(4):423-8.

21. Kawabata Y, Tanaka T, Nishi T, Monma H, Yano S, Tajima Y Appraisal of a total meso-pancreatoduodenum excision with pancreaticoduodenectomy for pancreatic head carcinoma. Eur $J$ Surg Oncol 2012;38(7):574-9.

22. Terakawa H, Kitagawa $H$, Makino I, Hayashi $H$, Oyama K, Nakagawara $\mathrm{H}$, et al. Location of the meso-pancreatoduodenum as a regional lymphatic basin for pancreatic head carcinoma. Oncol Lett 2017;14(1):397-403.
23. Chowdappa R, Challa VR. Mesopancreas in pancreatic cancer: where do we stand - review of literature. Indian J Surg Oncol 2015; 6(1):69-74

24. Osipov A, Nissen N, Rutgers J, Dhall D, Naziri J, Chopra S, et al. Redefining the Positive Margin in Pancreatic Cancer: Impact on Patterns of Failure, Long-Term Survival and Adjuvant Therapy. Ann Surg Oncol 2017;24(12):3674-82.

25. Perinel J, Adham $\mathrm{M}$. [Le mésopancréas: une réalité anatomique ou une assimilation hasardeuse?] e-mémoires de L'Académie Nationale de Chirurgie 2014;13(2):089-92.

26. Chandrasegaram MD, Goldstein D, Simes J, Gebski V, Kench JG, Gill AJ, et al. Meta-analysis of radical resection rates and margin assessment in pancreatic cancer. Br J Surg 2015;102(12):1459-72.

27. Verbeke CS, Menon KV. Redefining resection margin status in pancreatic cancer. HPB (Oxford) 2009;11(4):282-9.

28. Butturini G, Stocken DD, Wente MN, Jeekel H, Klinkenbijl JH, Bakkevold $\mathrm{KE}$, et al. Influence of resection margins and treatment on survival in patients with pancreatic cancer: meta-analysis of randomized controlled trials. Arch Surg 2008;143(1):75-83.

29. Delpero JR, Bachellier P, Regenet N, Le Treut YP, Paye F, Carrere N, et al. Pancreaticoduodenectomy for pancreatic ductal adenocarcinoma: a French multicentre prospective evaluation of resection margins in 150 evaluable specimens. HPB (Oxford) 2014;16(1):20-33.

30. Esposito I, Kleeff J, Bergmann F, Reiser C, Herpel E, Friess H, et al. Most pancreatic cancer resections are $\mathrm{R} 1$ resections. Ann Surg Oncol 2008:15(6):1651-60.

31. Jamieson NB, Foulis AK, Oien KA, Going JJ, Glen P, Dickson EJ, et al. Positive mobilization margins alone do not influence survival following pancreatico-duodenectomy for pancreatic ductal adenocarcinoma. Ann Surg 2010;251(6):1003-10.

32. Menon KV, Gomez D, Smith AM, Anthoney A, Verbeke CS. Impact of margin status on survival following pancreatoduodenectomy for cancer: the Leeds Pathology Protocol (LEEPP). HPB (Oxford) 2009;11(1):18-24.

33. Strobel O, Hank T, Hinz U, Bergmann F, Schneider L, Springfeld C, et al. Pancreatic Cancer Surgery: The New R-status Counts. Ann Surg 2017;265(3):565-73.

34. Verbeke CS, Leitch D, Menon KV, McMahon MJ, Guillou PJ, Anthoney A. Redefining the $\mathrm{R} 1$ resection in pancreatic cancer. $\mathrm{Br} \mathrm{J}$ Surg 2006;93(10):1232-7

35. Butler JR, Ahmad SA, Katz MH, Cioffi JL, Zyromski NJ. A systematic review of the role of periadventitial dissection of the superior mesenteric artery in affecting margin status after pancreatoduodenectomy for pancreatic adenocarcinoma. HPB (Oxford) 2016;18(4):305-11.

36. Kim KS, Kwon J, Kim K, Chie EK. Impact of Resection Margin Distance on Survival of Pancreatic Cancer: A Systematic Review and Meta-Analysis. Cancer Res Treat 2017:49(3):824-33.

37. Gockel I, Domeyer M, Wolloscheck T, Konerding MA, Junginger T. Resection of the mesopancreas (RMP): a new surgical classification of a known anatomical space. World J Surg Oncol 2007:5:44.

38. Gaedcke J, Gunawan B, Grade M, Szoke R, Liersch T, Becker H, et al. The mesopancreas is the primary site for $\mathrm{R} 1$ resection in pancreatic head cancer: relevance for clinical trials. Langenbecks Arch Surg 2010;395(4):451-8.

39. Dumitrascu T, Dima S, Popescu I. Update in pancreatic cancer surgery - focus on total mesopancreas excision. Maedica (Buchar) 2012;7(1):94-5

40. Agrawal MK, Thakur DS, Somashekar U, Chandrakar SK, Sharma D. Mesopancreas: myth or reality? JOP 2010;11(3):230-3.

41. Bouassida M, Mighri MM, Chtourou MF, Sassi S, Touinsi H, Hajji H, et al. Retroportal lamina or mesopancreas? Lessons learned by anatomical and histological study of thirty three cadaveric dissections. Int J Surg 2013;11(9):834-6.

42. Sharma D, Isaji S. Mesopancreas is a misnomer: time to correct the nomenclature. J Hepatobiliary Pancreat Sci 2016;23(12):745-9.

43. Nakao A. The Mesenteric Approach in Pancreatoduodenectomy. Dig Surg 2016;33(4):308-13. 
44. Kurosaki I, Minagawa M, Takano K, Takizawa K, Hatakeyama K. Left posterior approach to the superior mesenteric vascular pedicle in pancreaticoduodenectomy for cancer of the pancreatic head. JOP 2011;12(3):220-9

45. Lupascu C, Andronic D, Grigorean VT, Ursulescu C. Mesopancreas first dissection during pancreaticoduodenal resection: selective approach or paradigm? Hepatogastroenterology 2014;61(130): 463-8.

46. Sugiyama M, Suzuki Y, Nakazato T, Yokoyama M, Kogure M, Abe N, et al. Intestinal derotation procedure for facilitating pancreatoduodenectomy. Surgery 2016;159(5):1325-32.

47. Welsch T, Bork U, Distler M, Weitz J. Top-down approach to the superior mesenteric artery and the mesopancreas during pancreatoduodenectomy for pancreatic cancer. J Surg Oncol 2016;113(6):668-71.

48. Hartwig W, Gouma DJ, Charnley RM, Buchler MW. Reply to "Resection of the mesopancreas in pancreatic head adenocarcinoma: Is it outside of the International Study Group on Pancreatic Surgery definition and consensus statement for standard and extended pancreatectomy?". Surgery 2015;158(1):311-2.

49. Peparini N, Chirletti P. Clearance of the retropancreatic margin in pancreatic carcinomas: total mesopancreas excision or extended lymphadenectomy? Eur J Surg Oncol 2012;38(11):1146.

50. Peparini N, Chirletti P. Mesopancreas: a boundless structure, namely R1 risk in pancreaticoduodenectomy for pancreatic head carcinoma. Eur J Surg Oncol 2013;39(12):1303-8.

51. Peparini N. Mesopancreas: A boundless structure, namely the rationale for dissection of the paraaortic area in pancreaticoduodenectomy for pancreatic head carcinoma. World J Gastroenterol 2015;21(10):2865-70.

52. Nappo G, Perinel J, El BM, Adham M. The Standardization of Pancreatoduodenectomy: Where Are We? Pancreas 2016;45(4): 493-502.

53. Nakao A, Takagi H. Isolated pancreatectomy for pancreatic head carcinoma using catheter bypass of the portal vein. Hepatogastroenterology 1993;40(5):426-9.

54. Dumitrascu T, David L, Popescu I. Posterior versus standard approach in pancreatoduodenectomy: a case-match study. Langenbecks Arch Surg 2010;395(6):677-84.

55. Georgescu S, Ursulescu C, Grigorean VT, Lupascu C. Hind right approach pancreaticoduodenectomy: from skill to indications. Gastroenterol Res Pract 2014;2014:210835.

56. Moldovan SC, Dumitrascu T, Mensier A, Desurmont T, Dominguez $\mathrm{S}$, Cambier N, et al. A posterior approach pancreaticoduodenectomy with portal vein resection in a large adenocarcinoma of the uncinate process of the pancreas - case report. Chirurgia (Bucur ) 2015;110(2):161-4.

57. Pessaux P, Regenet N, Arnaud JP. [Resection of the retroportal pancreatic lamina during a cephalic pancreaticoduodenectomy: first dissection of the superior mesenteric artery]. Ann Chir 2003;128(9):633-6.

58. Sanjay P, Takaori K, Govil S, Shrikhande SV, Windsor JA. 'Artery-first' approaches to pancreatoduodenectomy. Br J Surg 2012;99(8):102735 .

59. Weitz J, Rahbari N, Koch M, Buchler MW. The "artery first" approach for resection of pancreatic head cancer. J Am Coll Surg 2010;210(2):e1-e4.

60. Xu YF, Liu ZJ, Gong JP. Pancreaticoduodenectomy with early superior mesenteric artery dissection. Hepatobiliary Pancreat Dis Int 2010;9(6): 579-83.

61. Negoi I, Hostiuc S, Runcanu A, Negoi RI, Beuran M. Superior mesenteric artery first approach versus standard pancreaticoduodenectomy: a systematic review and meta-analysis. Hepatobiliary Pancreat Dis Int 2017;16(2):127-38.

62. Pandanaboyana S, Bell R, Windsor J. Artery first approach to pancreatoduodenectomy: current status. ANZ J Surg 2016; 86(3):127-32.

63. Pal S, George J, Singh AN, Mathur S, Dash NR, Garg P, et al. Posterior Superior Mesenteric Artery (SMA) First Approach vs. Standard Pancreaticoduodenectomy in Patients with Resectable Periampullary Cancers: a Prospective Comparison Focusing on Circumferential Resection Margins. J Gastrointest Cancer 2017 Mar 18. Doi: 10.1007/s12029-017-9933-x. [Epub ahead of print]

64. Vallance AE, Young AL, Pandanaboyana S, Lodge JP, Smith AM. Posterior Superior Mesenteric Artery First Dissection Versus Classical Approach in Pancreaticoduodenectomy: Outcomes of a Case-Matched Study. Pancreas 2017;46(2):276-81.

65. Moldovan SC, Moldovan AM, Dumitrascu T, Andrei S, Popescu I. The advantages of retropancreatic vascular dissection for pancreatic head cancer with portal/superior mesenteric vein invasion: posterior approach pancreatico-duodenectomy technique and the mesopancreas theory. Chirurgia (Bucur ) 2012;107(5):571-8.

66. Kawabata Y, Nishi T, Tanaka T, Tajima Y. Safety and Feasibility of a Pancreaticoduodenectomy with Total Meso-Pancreatoduodenum Excision: Analysis in Various Periampullary Disorders. Hepatogastroenterology 2014;61(131):821-7.

67. Kawabata $\mathrm{Y}$, Hayashi H, Ishikawa N, Tajima Y. Total meso-pancreatoduodenum excision with pancreaticoduodenectomy in lower biliary tract cancer. Langenbecks Arch Surg 2016;401(4):463-9.

68. Kawabata Y, Tanaka T, Ishikawa N, Hayashi H, Tajima Y. Modified total meso-pancreatoduodenum excision with pancreaticoduodenectomy as a mesopancreatic plane surgery in borderline resectable pancreatic cancer. Eur J Surg Oncol 2016;42(5):698-705.

69. Inoue Y, Saiura A, Tanaka M, Matsumura M, Takeda Y, Mise Y, et al. Technical Details of an Anterior Approach to the Superior Mesenteric Artery During Pancreaticoduodenectomy. J Gastrointest Surg 2016; 20(10):1769-77.

70. Dumitrascu T, Popescu I. Posterior approach pancreaticoduodenectomy: does it really improve long-term survival in pancreatic head cancer? JOP 2011;12(5):491-2.

71. Dumitrascu T, Popescu I. Total mesopancreas excision in pancreatic head adenocarcinoma: The same impact as total mesorectal excision in rectal carcinoma? Comment on article "surgical technique and results of total mesopancreas excision in pancreatic tumours" by Adham M and Singhirunnusorn J, Eur J Surg Oncol, 2012. Eur J Surg Oncol 2012; 38(8):725.

72. Peparini N, Caronna R, Chirletti P. The "meso" of the rectum and the "meso" of the pancreas: similar terms but distinct concepts in surgical oncology. Hepatobiliary Pancreat Dis Int 2015;14(5):548-51.

73. Verbeke CS, Knapp J, Gladhaug IP. Tumour growth is more dispersed in pancreatic head cancers than in rectal cancer: implications for resection margin assessment. Histopathology 2011; 59(6):1111-21. 